\title{
MASS BALANCE OF ANTARCTIC ICE SHEET FROM 2003 TO 2008: A SYSTEMATICALLY IMPROVED NEW ESTIMATION
}

\author{
Rongxing $\mathrm{Li}^{1,2} *$, Huan Xie ${ }^{1,2}$, Yixiang Tian ${ }^{1,2}$, Wenjia Du ${ }^{1,2}$, Jiajin Chen ${ }^{1,2}$, Gang Hai ${ }^{1,2}$, Shanshan Zhang ${ }^{1,2}$, \\ Xiaohua Tong ${ }^{1,2}$ \\ ${ }^{1}$ Center for Spatial Information Science and Sustainable Development Applications \\ ${ }^{2}$ College of Surveying and Geo-Informatics \\ Tongji University, Shanghai 200092, China
}

(rli, huanxie, tianyixiang, 1351204, 1253507, ganghai, 1633316, xhtong)@ tongji.edu.cn

KEY WORDS: Antarctic, ice sheet, mass balance, ICESat

\begin{abstract}
:
There exist several results of mass balance of the Antarctic Ice Sheet (AIS) estimated based the laser altimetry ICESat, especially for some with a significant difference. In this study, we attempt to use the ICESat data to re-estimate the mass balance of the AIS over 2003-2008 by making several systematic improvements in data processing and model construction. We applied all corrections to the ICESat data including the re-estimation of the ICB. A three-step model was used in different area for calculating elevation changes of the Antarctica ice sheet. The elevation change rate was compared with other results generated from Global Position System (GPS), stakes, Airborne Terrain Mapper (ATM) and CHINRE data. These verification data proved a good agreement between each other considering the uncertainty involved. We also corrected the component in the elevation change rates that do not contribute to the mass loss such as the global isostatic correction and firn compaction. The corrected elevation change result was converted to the mass change using a surface density model.
\end{abstract}

\section{INTRODUCTION}

The fifth IPCC assessment report mentioned that the global sea level has increased $0.19 \mathrm{~m}$ in the past 100 years. The rate of sea level rising is still in acceleration and expected to increase by $0.18-0.59 \mathrm{~m}$ by the end of the 21 st century, which will lead to a series of social and environmental issues (International Panel on Climate Change, IPCC5; Stocker et al., 2014). As one of the two remaining ice sheets on the earth, the state of the Antarctic Ice Sheet (AIS, Figure 1) and associated global sea level rise are an important indicator of the impact of global climate change. Studies have shown that fresh water stored in Antarctic ice sheets can raise the global sea level by about $60 \mathrm{~m}$ (Fretwell et al., 2013). With the rapid development of industry in the past 100 years, greenhouse gas emissions, marine pollution, global temperature rising, the melting of the Antarctic ice sheet is deteriorating and accelerating (Shepherd et al., 2012). In the past 20 years, the rate of loss of the Antarctic ice sheet has increased from -30 Gt per year over 1992-2001 to -147 Gt per year over 2002-2011 (Stocker et al., 2014). The quantitative remote sensing analysis of the AIS mass balance focuses on three techniques: input-output, gravimetry and satellite altimetry (Rignot et al., 2019; Shepherd et al., 2018). Among these methods, satellite laser altimetry can provide detailed distribution of the mass changes and accurate overall estimate due to its high spatial resolution, high precision and negligible snow penetration. (Shepherd et al., 2012). One of the uncertainties of the ICESat estimate lies in the InterCampaign Bias (ICB) and the density model to convert elevation changes to amass balance (Scambos et al., 2016; Richter et al., 2015). Here we analyzed ICESat data processing method and compared with the published ones (Hofton et al., 2013; Helm et al., 2014; Gunter et al., 2014; Richter et al., 2014; Zwally et al., 2015). The elevation estimation model were improved with the seasonal parameters and the density model was also improved with in-situ density data (Sørensen et al., 2011; McMillan et al., 2014; Schröder et al., 2018; Tian et al., 2018). We produced a systematically improved result of the mass balance of Antarctic ice sheet during 2003-2008 based on ICESat data.

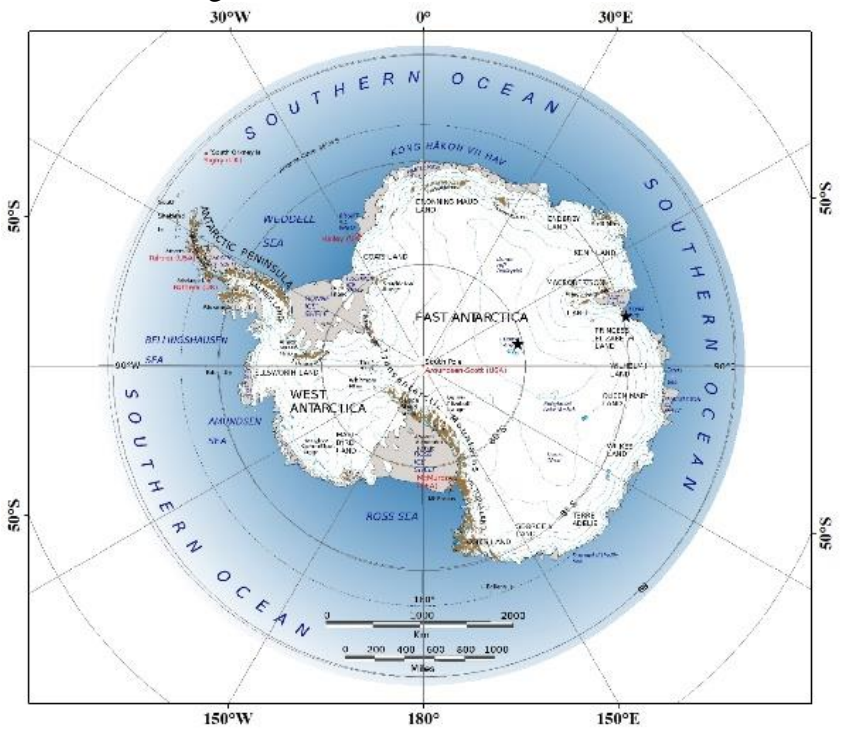

Figure 1. The Antarctic ice sheet overview map, the background image is adapted from the Landsat Image Mosaic of Antarctica (Bindschadler et al., 2008).

\section{DATA AND METHOD}

\subsection{ICESat Data and Processing}

ICESat (Ice, Cloud, and land Elevation Satellite) is the first laser altimeter satellite, belonging to the Earth observation system deployed by NASA. ICESat was launched at the Vandenberg Air Force Base in California on January 13, 2003 and officially 
retired in February 2010 (Schutz et al., 2005). The Earth Science Laser Height Measurement System (GLAS) is the sensor carried on ICESat to measure ice sheet topography (Abshire et al.,2005).

We used the updated ICESat GLA12 dataset (R634) (ftp://n5eil01u.ecs.nsidc.org/SAN/GLAS/GLA12.034/), which is corrected for the Gaussian-centroid (G-C) correction relative to the early release (Zwally et al., 2015; Sun et al., 2017). The saturation correction is flagged in the data files and we applied them for the relevant measurements (NSIDC, 2010; Sun et al., 2017). This product has 18 campaigns from January 2003 to October 2009 (Table 1). Laser 2 was operated for six campaigns (L2A, L2B, L2C, L2D, L2E, L2F) with a break of four years between campaigns L2C and L2D. Since the laser 2'energy was predicted not to be enough to go through another full campaign, the science team made the decision to switch to Laser 3 for subsequent campaigns. At the end of Laser 3's lifetime, operations were switched back to Laser 2 until the end of its lifetime. Considering sensor issues and data quality, we selected 15 campaigns from 2A to 2D (October 2003 to December 2008).

\begin{tabular}{|c|c|c|}
\hline Campaign & Period & Cycle \\
\hline $1 \mathrm{~A}$ & $2003-02-20 \sim 2003-03-21$ & 8-day \\
\hline $1 \mathrm{~B}$ & 2003-03-21 2003-03-29 & 8-day \\
\hline $2 \mathrm{~A}$ & 2003-09-25 2003-10-04 & 8-day \\
\hline $2 \mathrm{~A}$ & 2003-10-04 2003-11-19 & 91-day \\
\hline $2 \mathrm{~B}$ & 2004-02-17 2004-03-21 & 91-day \\
\hline $2 \mathrm{C}$ & 2004-05-18 2004-06-21 & 91-day \\
\hline $3 \mathrm{~A}$ & $2004-10-03 \sim 2004-11-08$ & 91-day \\
\hline $3 \mathrm{~B}$ & $2005-02-17 \sim 2005-03-24$ & 91-day \\
\hline $3 \mathrm{C}$ & $2005-05-20 \sim 2005-06-23$ & 91-day \\
\hline $3 \mathrm{D}$ & $2005-10-21 \sim 2005-11-24$ & 91-day \\
\hline $3 \mathrm{E}$ & $2006-02-22 \sim 2006-03-28$ & 91-day \\
\hline $3 \mathrm{~F}$ & $2006-05-24 \sim 2006-06-26$ & 91-day \\
\hline $3 \mathrm{G}$ & $2006-10-25 \sim 2006-11-27$ & 91-day \\
\hline $3 \mathrm{H}$ & 2007-03-12 2007-04-14 & 91-day \\
\hline $3 \mathrm{I}$ & $2007-10-02 \sim 2007-11-05$ & 91-day \\
\hline $3 \mathrm{~J}$ & 2008-02-17 2008-03-21 & 91-day \\
\hline $3 \mathrm{~K}$ & 2008-10-04 2008-10-19 & 91-day \\
\hline $2 \mathrm{D}$ & $2008-11-25 \sim 2008-12-17$ & 91-day \\
\hline $2 \mathrm{E}$ & 2009-03-09 2009-04-11 & 91-day \\
\hline $2 \mathrm{~F}$ & 2009-09-30 2009-10-11 & 91-day \\
\hline
\end{tabular}

Table 1. Campaigns and corresponding period of ICESat.

We performed data preprocessing, which involved data filtering, data classification, projection and transformation (Bamber et al., 2009). Another important correction for ICESat data when using ICESat GLAS altimetry data to assess temporal elevation changes requires consideration of variations in different working periods which can be defined as constant elevation biases over each of the mission campaigns. This correction can be defined as Inter-campaign Bias (ICBs) (Scambos et al., 2016; Schröder et al., 2017). It can be adjusted by measuring the elevation change over an almost unchanging surface which includes a large number of GLAS laser shots covering most or all of the ICESat campaigns. Several groups have used different version data to evaluate ICBs. The existing ICB includes the value estimated at Vostok (Helm et al., 2013), low-precipitation zone (LPZ, Gunter et al.,2014), $86^{\circ}$ rings (Hofton et al., 2013), open ocean (Shepherd et al., 2012; Urban et al., 2013; Zwally et al., 2015) and so on. Inter-campaign bias affected the trend with a range of $-1.43 \sim 1.67 \mathrm{~cm} \mathrm{a}^{-1}$ (NSIDC, 2017).

We discussed the published ICESat ICB assessments (Hofton et al., 2013, Helm et al., 2014, Borsa et al., 2014, Richter et al., 2014, Urban et al., 2015, Zwally et al., 2015, Schröder et al., 2017). The ICBs estimated over the ice sheet are found to have a higher correlation in both laser2 and laser3 campaigns and we applied our fitting result of them in this study.

\subsection{Elevation estimation and verification}

After the data pre-processing and the corrections, the altimetry data is used to calculate the elevation change rate of the Antarctic ice sheet. ICESat has more data and smaller intervals over high latitude region. The orbital spacing is big at low latitudes, and the terrain changes in coastal areas are large and the data quality is relatively low. In order to make the best use of ICESat data and get an accurate elevation change rate, we applied a three-step model to estimate the elevation changes for AIS from 2003 to 2008 considering the terrain parameters and seasonal variations. The distribution of the three model is shown if Figure 2.

Firstly, for the area which has high density data (mostly in the inner area of Antarctica), we utilized a simplified spatial/temporal polynomial model based on Ewert et al., 2012 and Schenk and Csathó, 2012 to characterize the ice surface topography and elevation trend considering both the surface slope and seasonal signal in the $500 \mathrm{~m} \times 500 \mathrm{~m}$ grid. We calculate Least Squares solution for trend and the related parameters. In order to guarantee enough signal for seasonal variations, we only applied the first model to grids where the number of points is more than 15 and the period is longer than 3.5 years. Seasonal signal can be estimated by equation (1):

$$
\mathrm{S}(\mathrm{t})=\operatorname{Acos}\left(\frac{2 \pi}{T}\left(t_{i}-\bar{t}\right)\right)+\mathrm{B} \sin \left(\frac{2 \pi}{T}\left(t_{i}-\bar{t}\right)\right)
$$

with amplitude $\mathrm{D}=\sqrt{A^{2}+B^{2}}$, period $\mathrm{T}$ is 365 days and $\mathrm{t}_{\mathrm{i}}$ is the time of each observation. We can get the seasonal change amplitude and the uncertainty over the most of the ice sheet area. A pattern was found as expected, which shows large seasonal amplitude in the coastal regions and little in the interior part of the ice sheet.

Secondly, if the ICESat data within the $500 \mathrm{~m} \times 500 \mathrm{~m}$ grid cannot meet the above requirements to get the model parameters, we applied a simplified version of the first-step method including height change and local topography, and without the seasonal signal (Xie et al., 2016). The restricted conditions we applied for grids are at least 10 points and over 2.5 years.

Thirdly, for the relative low latitude area of Antarctic Peninsula and the margin of the ice sheet, where the ICESat footprint distributions are very sparse, we evaluated the elevation change using a linear solution along cross-track direction with terms of slope and elevation change trend (Zwally et al., 2011). We interpolated ICESat points equally with an interval of $172 \mathrm{~m}$ along reference track. Within each box used in the trend 
estimation, the least squares process was used in a condition of redundant observations to control the error as well as parameter uncertainties based on the error propagation law (Ewert et al., 2012, Xie et al., 2016). The uncertainty of the trend in a box can be calculated and furthermore, we estimated the uncertainties in the $30 \mathrm{~km} \times 30 \mathrm{~km}$ cells and then in the basins by using the scaled median absolute deviation (MAD) adopted from Ewert et al., 2012, which does not require a normal distribution.

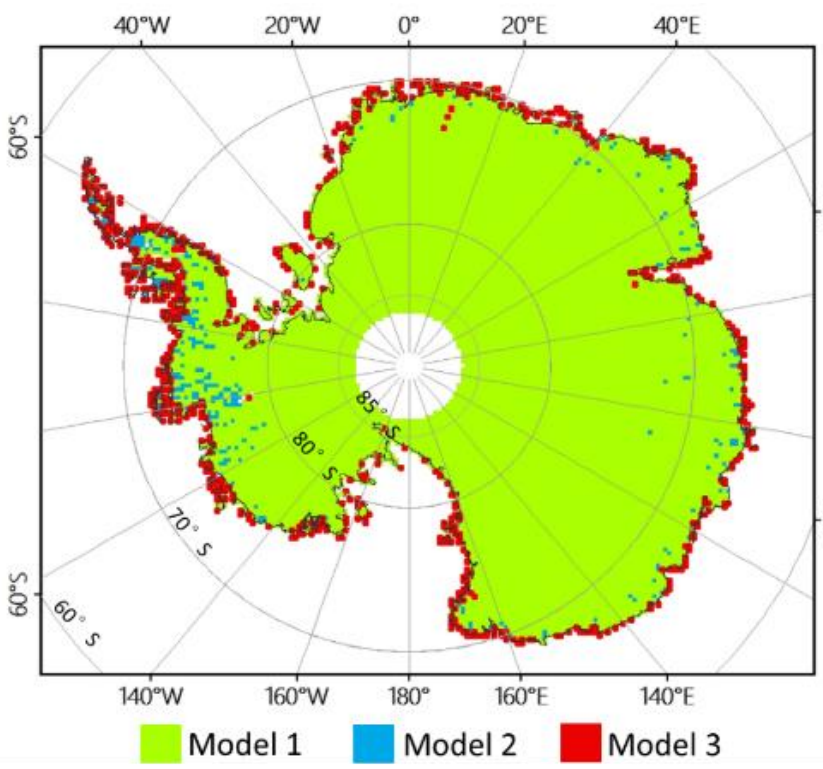

Figure 2. The distribution of the three models.

The elevation change value and uncertainty are calculated over the drainage basin level based on the subarea defined by Zwally et al.,2015 (Figure 3). To validate our elevation change rate results, we compared them with other airborne data or in-situ measurements, including GPS (Global Position System) data over the Subglacial Lake Vostok and Pine Island Glacier, ATM (Airborne Terrain Mapper) data over the Antarctic Peninsula and CHINARE field measurements from Zhongshan Station to Dome A (Richter et al., 2014; Scott et al., 2009; Zwally et al., 2015; Helm et al., 2014; Xie et al., 2016). The results of comparative analysis proved the rationality and accuracy of our solution for estimating the elevation change rate.

\subsection{Convert volume to mass}

There are several commonly used methods for converting from elevation changes to mass changes. The first method is to multiply the corrected elevation changes by a density constant in the conversion, for example, $900 \mathrm{~kg} \mathrm{~m}^{-3}$ in Zwally et al. (2005) and Groh et al. (2014). The second method multiplies elevation changes in different regions by different densities. Sørensen et al. (2011) used the surface snow density in areas above the ablation balance line and the ice density in areas below the equilibrium line. Gunter et al. (2014) calculated the difference in mass changes observed by GRACE and ICESat for estimating the glacial isostatic adjustment (GIA). The elevation change rate obtained by ICESat were compared with the surface elevation change rate and also considered their uncertainties to confirm each grid multiplied by ice density or surface density. McMillan et al. (2014) used a density mask for the conversion, multiplying the area of the fast ice flow by the density of the ice, and multiplying the remaining area by $350 \mathrm{~kg} \mathrm{~m}^{-3}$. Schröder et al. (2019) used the density mask of McMillan et al., but the remaining area is multiplied by the surface density model published by Ligtenberg et al. (2011). The third method calculates the surface mass balance separately from the dynamic mass balance. For example, in Schenk et al. (2014) and Zwally et al. (2015) surface mass balance is calculated from regional climate models, such as ERA and RACMO. The elevation changes caused by the firn compaction and GIA are deducted from the total changes observed by ICESat to obtain the dynamicdriven elevation changes that are then multiply by the density of ice to get the dynamic mass change.

The results of comparative analysis proved the rationality and accuracy of our solution for estimating the elevation change rate. To convert the volume result to mass result, the elevation changes caused by glacial isostatic adjustment (GIA) and firn densification need to be removed, which do not contribute to mass change. We corrected the firn compaction-caused height change, which is influenced by surface accumulation (field observations, ERA-Interim) and temperature variation (AVHRR surface temperature). We used mean surface temperature from 1982 to 1984 and field accumulation as input into the firn densification model (Zwally et al., 2015) to get the initial density profile, and then simulating densification rate during ICESat measure period by inputting monthly AVHRR temperature and ERA-Interim accumulation from 1982 to 2008. Then we constructed a surface snow density model based upon collected open-access field measurements around Antarctica, together with EOF and a matrix completion algorithm adjusted for snow/ice density. The density comparison between our result and other model results has been implemented. After that, the ice sheet will be divided into different zones by some rules and then converted from elevation change to mass with different ice/snow densities. In the ablation zone, the volume result is directly multiplied by an ice density, while our density model is used for the accumulation zone.

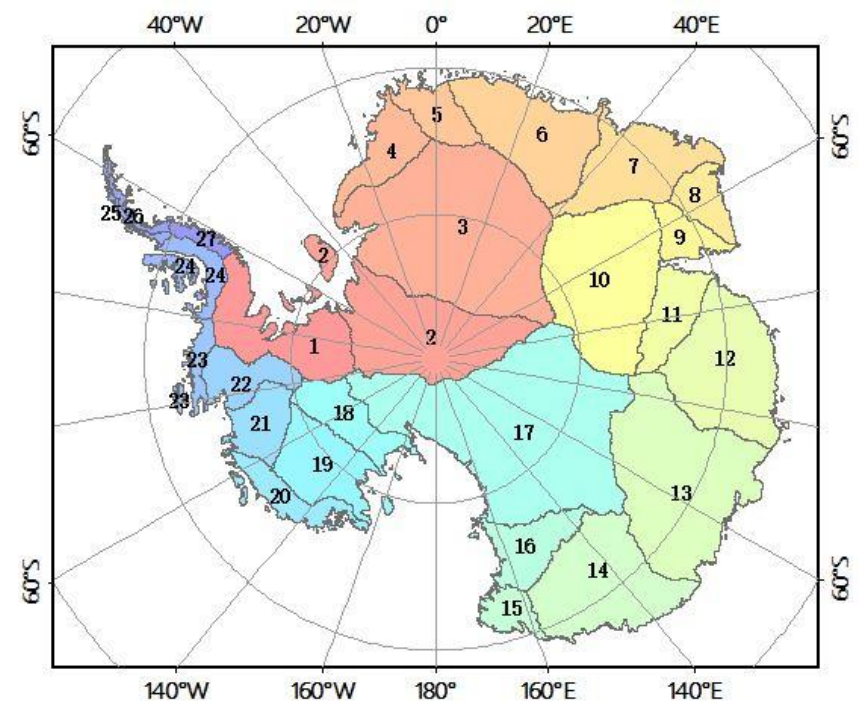

Figure 3. The drainage basins of the Antarctica Ice Sheet (Zwally et al., 2015). The Antarctic ice sheet is divided into 27 basins. The East Antarctic and West Antarctic ice sheets (EAIS and WAIS, respectively) are roughly separated along the TransAntarctic Mountains. The EAIS is divided into 16 basins (2-17), the WAIS is divided into 7 basins $(1,18-23)$ and the Antarctic Peninsula is divided into 4 basin basins (24-27). 


\section{CONCLUSION}

We used the R634 ICESat data with the all corrections including the Gaussian-centroid (G-C) correction, saturation correction, GIA, firn compaction and a re-estimation ICB in our data processing. We combined three models to estimate the elevation change rate and error of the AIS, considering the influence of seasonal variations on the model solution. We combined results from different models, then re-sampling the rate to $30 \mathrm{~km}$ resolution, and the elevation change rate of each basin is calculated for statistics. Using measured data from various data sources such as airborne and ground observations, we validated our ICESat derived elevation change rate in the Vostok region of the Antarctic (stable ice lake area), PIG (rapid ablation zone), Smith Glacier (rapid ablation ice flow), Antarctic Peninsula (less observations zone) and the CHINARE Tranverse (Chinese scientific section). Results show that the elevation change calculated from ICESat was consistent with the airborne and ground observation.An improved density model was also used with in-situ density data when converting the volume result to mass change. We will present at the workshop the improved result of the mass balance of Antarctic ice sheet over 2003-2008.

\section{ACKNOWLEDGEMENTS}

The work was substantially supported by National Key R\&D Program of China (Grant No. 2017YFA0603100), Outstanding Youth Science Program and General Program of National Natural Science Foundation of China (Grant No. 41822106 and 41571407). We would like to thank NSIDC for providing the ICESat data.

\section{REFERENCES}

Abshire, J. B., Sun, X., Riris, H., Sirota, J. M., McGarry, J. F., Palm, S., ... \& Liiva, P., 2005. Geoscience laser altimeter system (GLAS) on the ICESat mission: on-orbit measurement performance. Geophysical research letters, Vol. 32(21).

Bamber, J.L., Gomez-Dans, J.L. and Griggs, J.A., 2009. A new $1 \mathrm{~km}$ digital elevation model of the Antarctic derived from combined satellite radar and laser data-Part 1: Data and methods. The Cryosphere, Vol. 3, pp. 101-111.

Bindschadler, R., Vornberger, P., Fleming, A., Fox, A., Mullins, J., Binnie, D., \& Gorodetzky, D., 2008. The Landsat image mosaic of Antarctica. Remote Sensing of Environment, Vol. 112(12), pp. 4214-4226.

Ewert, H., Groh, A., Dietrich, R., 2012. Volume and mass changes of the Greenland ice sheet inferred from ICESat and GRACE. Journal of Geodynamics, Vol. 59(SI), pp. 111-123.

Fretwell, P., Fretwell, P., Pritchard, H.D., Vaughan, D.G., Bamber, J.L., Barrand, N.E., Bell, R., and Catania, G.A., 2013. Bedmap2: improved ice bed, surface and thickness datasets for Antarctica. The Cryosphere, Vol. 7, pp. 375-393.

Groh, A., Ewert, H., Rosenau, R., Fagiolini, E., Gruber, C., Floricioiu, D., Abdel Jaber, W., Lindow, S., Flechtner, F. Eineder, M., Dierking, W. Dietrich, R., 2014. Mass, volume and velocity of the Antarctic ice sheet: present-day changes and error effects. Surveys in Geophysics, Vol. 35(6), pp. 1481-1505.

Gunter, B.C., Didova, O., Riva, R.E.M., Ligtenberg, S.R.M., Lenaerts, J.T.M., King, M.A., van den Broeke, M.R. and Urban,
T., 2014. Empirical estimation of present-day Antarctic glacial isostatic adjustment and ice mass change. The Cryosphere, Vol. 8(2), pp.743-760.

Helm, V., Humbert, A., Miller, H., 2014. Elevation and elevation change of Greenland and Antarctica derived from CryoSat-2. The Cryosphere, Vol. 8(4), pp. 39-1559.

Hofton, M.A., Luthcke, S.B., and Blair, J.B., 2013. Estimation of ICESat intercampaign elevation biases from comparison of lidar data in East Antarctica. Geophysical Research Letters, Vol. 40(21), pp. 5698-5703.

Ligtenberg, S.R.M., Heilsen, M.M., and van de Broeke, M.R., 2011. An improved semi-empirical model for the densification of Antarctic firn. The Cryosphere, Vol. 5(4), pp. 809-819.

McMillan, M., Shepherd, A., Sundal, A., Briggs, K., Muir, A., Ridout, A., Hogg A. and Wingham, D., 2014. Increased ice losses from Antarctica detected by CryoSat-2. Geophysical Research Letters, Vol. 41(11), pp. 3899-3905.

Richter, A., Popov, S.V., Fritsche, M., Lukin, V.V., Matveev, A.Y., Ekaykin, A.A., Lipenkov, V.Y., Fedorov, D.V., Eberlein, L., Schroder, L., Ewert, H., Horwath, M. and Dietrich, R., 2014. Height changes over subglacial Lake Vostok, East Antarctica: insights from GNSS observations. Journal of Geophysical Research: Earth Surface, Vol. 119(11), pp. 2460-2480.

Rignot, E., Mouginot, J., Scheuchl, B., van den Broeke, M., van Wessem, M. J., Morlighem, M., 2019. Four decades of Antarctic Ice Sheet mass balance from 1979-2017. Proceedings of the National Academy of Sciences, Vol. 116(4), pp. 1095-1103.

Scambos, T., Shuman, C., 2016. Comment on 'Mass gains of the Antarctic ice sheet exceed losses' by HJ Zwally et al. Journal of Glaciology, Vol. 62(233), pp. 599-603.

Schröder, L., Richter, A., Fedorov, D. V., Eberlein, L., Brovkov, E. V., Popov, S. V., ... \& Scheinert, M., 2017. Validation of satellite altimetry by kinematic GNSS in central East Antarctica. The Cryosphere, Vol. 11(3), pp. 1111-1130.

Schröder L., Horwath M., Dietrich R., Helm V., 2019. Four decades of surface elevation change of the Antarctic Ice Sheet from multi-mission satellite altimetry. The Cryosphere, Vol. 13, pp. $427-449$.

Schenk, T., Csatho, B., 2012. A new methodology for detecting ice sheet surface elevation changes from laser altimetry data. IEEE Transactions on Geoscience and Remote Sensing, Vol. 50(9), pp. 3302-3316.

Schutz, B. E., Zwally, H. J., Shuman, C. A., Hancock, D., \& DiMarzio, J. P., 2005. Overview of the ICESat mission. Geophysical Research Letters, Vol. 32(21).

Scott, J.B., Gudmundsson, H., Smith, A.M., Bingham, R.G., Pritchard, H.D., and Vaughan, D.G., 2009. Increased rate of acceleration on Pine Island Glacier strongly coupled to changes in gravitational driving stress. The Cryosphere, Vol. 3(1), pp. 125-131.

Shepherd, A., Ivins, E., Rignot, E., Smith, B., Van Den Broeke, M., Velicogna, I., and Nowicki, S., 2018. Mass balance of the Antarctic ice sheet from 1992 to 2017. Nature, Vol. 558, pp. 219222 
Shepherd, A., and 46 others, 2012. A reconciled estimate of icesheet mass balance. Science, Vol. 338(6111), pp. 1183-1189.

Stocker, T.F., Qin, D., Plattner, G.K., Tignor, M., Allen, S.K., Boschung, J., and Midgley, B.M., 2014. Climate change 2013: The physical science basis.

Sun, X., Abshire, J. B., Borsa, A. A., Fricker, H. A., Yi, D., DiMarzio, J. P., ... \& Neumann, G. A., 2017. ICESat/GLAS altimetry measurements: received signal dynamic range and saturation correction. IEEE Transactions on Geoscience and Remote Sensing, Vol. 55(10), pp. 5440-5454.

Sørensen, L.S., Simonsen, S.B., Nielsen, K., Lucas-Picher, P., Spada, G., Adalgeirsdottir, G., Forsberg, R., Hvidberg, C.S., 2011. Mass balance of the Greenland ice sheet (2003-2008) from ICESat data-the impact of interpolation, sampling and firn density. The Cryosphere, Vol. 5, pp. 173-186.

Tian, Y.X., Zhang, S.S., Du, W.J., Chen, J.J., Xie, H., Tong, X.H., Li, R.X., 2018. Surface snow density of East Antarctica derived from in-situ observations. International Archives of the Photogrammetry, Remote Sensing \& Spatial Information Sciences, Vol. 42(3).

Urban, T.J., Pie, N., Felikson, D., and Schutz, B.E., 2013. Impacts on Greenland and Antarctica ice sheet mass balance from estimation of ICESat-1/GLAS inter-campaign elevation biases over the oceans. In AGU Fall Meeting Abstracts Vol. 1, 0660 .

Xie H., Li R., Tong X., et al., 2016. A comparative study of changes in the Lambert Glacier/Amery Ice Shelf system, East Antarctica, during 2004-2008 using gravity and surface elevation observations. Journal of Glaciology, Vol. 62(235), pp. 888-904.

Zwally, H.J., Giovinetto, M.B., Li, J., Cornejo, H.G., Beckley, M.A., Brenner, A. C., Saba, J.L. and Yi, D., 2005. Mass changes of the Greenland and Antarctic ice sheets and shelves and contributions to sea-level rise: 1992-2002. Journal of Glaciology, Vol. 51(175), pp. 509-527.

Zwally H J, Li J, Brenner A C, et al, 2011. Greenland ice sheet mass balance: distribution of increased mass loss with climate warming; 2003-07 versus 1992-2002. Journal of Glaciology, Vol. 57(201), pp. 88-102.

Zwally, H.J., Li, J., Robbins, J.W., Saba, J.L., Yi, D., and Brenner, A.C., 2015. Mass gains of the Antarctic ice sheet exceed losses. Journal of Glaciology, Vol. 61(230), pp. 1019-1036. 